\title{
Police Misconduct as a BREACH OF Public TRust: The OfFEnCE OF Misconduct in Public OfFice
}

\section{CInDY DAVIDS*}

\section{MARILYN MCMAHON**}

Until relatively recently, the common law offence of misconduct in public office has been regarded as anachronistic. The offence was perceived to have been supplanted by specific statutory offences that could more appropriately deal with criminal conduct by public officials. However, there has been a revival of the offence with successful prosecutions occurring in Australia, England and Hong Kong. Many of these contemporary cases have involved police officers. Examination of these cases reveals that the circumstances in which misconduct in public office has been identified have been diverse, including the unauthorised disclosure of confidential information, the use of false search warrants and the sexual exploitation of vulnerable persons. In many instances, police officers were charged with other criminal offences in addition to charges relating to misconduct in public office. The matters prosecuted as misconduct in public office typically involved matters that were serious and/or could not be adequately prosecuted as other criminal offences or as breaches of police regulations governing conduct. Consequently, despite the proliferation of statutory criminal offences in the $20^{\text {th }}$ century it appears that there continues to be a place for the offence of misconduct in public office. It criminalises misconduct by police officers that may not be adequately dealt with by other offences and recognises the public trust dimension of wrongdoing by these officials. However, a continuing and fundamental challenge is to determine the appropriate definition and scope of the offence.

\section{INTRODUCTION}

Public knowledge of improper conduct by parliamentarians, local elected officials, and public officials at various levels (public or civil servants), can lead to a reduced level of confidence and trust in democratic institutions and,

\footnotetext{
* Associate Professor, School of Law, Deakin University.

** Associate Professor, School of Law, Deakin University.
} 
in extreme cases, to an erosion of their claims to legitimacy. ${ }^{1}$ It may also lead to a broader culture of cynicism, with other occupational groups able to point to examples of double standards set by those occupying the highest public offices. Such improper conduct itself represents an abuse of the public office that is held by the person concerned - it violates both the public trust that attaches to the holding of public office and the integrity that is expected of those occupying such positions.

The problem of misconduct in public office has at its heart the issue of trust and the notion that public officials who hold and exercise power and authority must be accountable to the public. The offence of misconduct in public office involves, broadly speaking, a wilful neglect of duty, or wilful misconduct, by a public officer that amounts to an abuse of the public trust. ${ }^{2}$ Establishing the distinct offence of misconduct in public office has its roots in a desire to penalise behaviours - acts and omissions - which fall egregiously short of acceptable standards of behaviour from public office holders; and where standard organisational disciplinary responses are regarded as, in themselves, inadequate in relation to the gravity of the misconduct.

In the domain of policing, the process of holding individual police officers to account for misconduct is set against a complex background of formal disciplinary and regulatory frameworks, various laws, rules and regulations, and myriad practices of informal social control that exist within the cultural milieu of police organisations. The standard method of operationalising individual police officer accountability is through a formal police discipline system, which may be invoked when a member of the public or other affected person makes a formal complaint about perceived problematic behaviour. Police discipline systems follow internal (organisational) procedures, although there may also be external police complaints bodies and/or independent agency oversight. ${ }^{3}$ On occasion, particularly in relation to matters involving serious misconduct, a less frequent path of criminal charges against a police officer may be pursued.

This article examines the way in which the public trust invested in public officials is now being extended to police officers and protected through the offence of misconduct in public office. It traces the re-emergence in the late

\footnotetext{
${ }^{1}$ For example, Transparency International (TI) Australian Director, Michael Ahrens, explained that a four-point drop in Australia's score in the TI Corruption Perceptions Index 2013 could be partly due to corruption findings against New South Wales (NSW) politicians and generally perceived corruption in the (then) NSW government (see Transparency International Australia, Update No 177, December 2013).

${ }^{2}$ Attorney General's Reference No 3 of 2003 [2004] EWCA Crim 868 ('AG Reference No 3’).

${ }^{3}$ Cindy Davids, Conflict of Interest in Policing: Problems, Practices, and Principles (Sydney, Institute of Criminology Press, 2008).
} 
$20^{\text {th }}$ century of a longstanding common law offence that had fallen into disuse. The contemporary application of the offence of misconduct in public office to criminal behaviour by police has involved considerable development and elaboration of an offence that has its roots in early notions of public trust invested in public officials. The elements involved in pursuing this common law offence are examined by reference to recent cases in Victoria, Australia. Cases from the United Kingdom and a third common-law jurisdiction that has seen successful prosecution and conviction of police officers utilising the offence of misconduct in public office - Hong Kong — are also drawn upon to explore the nature of this offence.

The article analyses the elements of the offence, focusing on:

- the scope of the term 'public official';

- the distinctions between police officer behaviour on and off duty and between actions in the course of or in relation to official duties or functions;

- $\quad$ the requirement of wilful and intentional misconduct;

- $\quad$ the required seriousness of the misconduct; and

- the importance of the concept of the 'public interest'.

Concerns, particularly from the United Kingdom, around issues of double jeopardy are also considered. Finally, utilising case detail from recent prosecutions, the article seeks to provide a nuanced understanding of the circumstances giving rise to prosecution of police officers for misconduct in public office, considering the particular public interest that the offence seeks to protect.

\section{The Offence of Misconduct in Public Office}

\section{A Historical Background}

The offence of misconduct in public office can be traced back to the $18^{\text {th }}$ century. In 1704, in Anonymous, the court held: 
If a man be made an officer by Act of Parliament, and misbehave himself in his office, he is indictable for it at common law, and any publick officer is indictable for misbehaviour in his office. ${ }^{4}$

By the late $18^{\text {th }}$ century, the offence was further consolidated, and the range of persons regarded as 'public officers' was extended to those holding an 'office of trust'. In $R v$ Bembridge, Lord Mansfield stated:

Here there are two principles applicable: first, that a man accepting an office of trust concerning the public, especially if attended with profit, is answerable criminally to the King for misbehaviour in his office; this is true, by whomever and in whatever way the officer is appointed ... Secondly, where there is a breach of trust, fraud, or imposition, in a matter concerning the public, though as between individuals it would only be actionable, yet as between the King and the subject it is indictable. That such should be the rule is essential to the existence of the country. ${ }^{5}$

By the late $19^{\text {th }}$ century, Sir James Fitzjames Stephen defined 'public officer' broadly as 'a person invested with authority to execute any public duty, and legally bound to do so'. ${ }^{6}$ In 1914 , the court in $R v$ Whitaker more expansively noted:

A public office holder is an officer who discharges any duty in the discharge of which the public are interested, more clearly so if he is paid out of a fund provided by the public. ${ }^{7}$

The ambit of 'public officer' was subsequently extended to cover a wide variety of public officials, including persons who act in an unpaid, voluntary capacity. ${ }^{8}$

The scope of the offence was also extended. Early cases tended to prosecute misconduct involving fraud and bribery. However, the definition of 'misconduct' eventually expanded beyond fraud and deceits in office to encompass a 'great variety of circumstances'. 9

\footnotetext{
${ }^{4}$ (1704) 6 Mod 96; 87 ER 853.

${ }^{5}$ (1783) 3 Dougl 327; 99 ER 679.

${ }^{6}$ The definition excluded 'any member of either House of Parliament as such, or any ecclesiastical, naval, or military officer acting in the discharge of duties for the due discharge of which he can be made accountable only by an ecclesiastical, naval, or military court': James Fitzjames Stephen, A Digest of the Criminal Law (Crimes and Punishments), (Macmillan, 4th ed, 1887) 83 <https://archive.org/details/adigestcriminal02stepgoog>.

${ }^{7}$ [1914] 3 KB 1283.

${ }^{8} R v$ Belton [2010] WLR (D) 283.

${ }^{9}$ AG Reference No 3 [2004] EWCA 868 [54] (Roderick Evans J).
} 
In a seminal work on official misconduct, Finn cited various examples of conduct falling within the scope of the common law offence, illustrating its broad nature:

(a) frauds and deceits by officers (fraud in office) as where a consular official misappropriates moneys which he is duty bound to remit to a Government department;

(b) wilful neglect of duty (nonfeasance) as where a police officer wilfully refuses to enforce the law;

(c) 'malicious' exercise of official power (misfeasance) as where licensing authorities grant or refuse an application for reasons known to be improper;

(d) wilful excesses of official authority (malfeasance), as where a magistrate assumes to act in a matter known to be beyond the competence of his office; and

(e) the intentional infliction of bodily harm, imprisonment, or other injury upon a person (oppression) as where a justice, without authority, orders a person to be whipped. ${ }^{10}$

Despite the expansion in the definition of 'public office' and the broadening of the circumstances that could constitute misconduct, by the middle of the $20^{\text {th }}$ century the offence was rarely prosecuted. A complicating factor was that, in those infrequent matters where such a charge was laid, it was generally conceded that there was some uncertainty in the definition of the offence. Thus, Widgery $\mathrm{J}$ observed in $R v$ Llewellyn Jones ${ }^{11}$ that it was not easy to lay down with precision the parameters of misconduct or misbehaviour that was covered by the offence. The South Australian Court of Criminal Appeal expressed similar concerns in Question of Law Reserved (No 2 of 1996), ${ }^{12}$ which dealt with three police officers accessing and disclosing confidential information to a third party.

\section{B Responding to Uncertainty}

Two responses emerged to the uncertainty inherent in the offence of misconduct in public office: to prefer other, specific criminal charges rather

\footnotetext{
${ }^{10}$ Paul Finn, 'Official Misconduct' (1978) 2(6) Criminal Law Journal 307, 310-11.

${ }^{11}$ (1967) 51 Cr App R 4, 6.

${ }^{12}$ (1996) 67 SASR 63.
} 
than prosecute for the common law offence; or to overhaul the offence by adopting a statutory formulation. ${ }^{13}$

Many legal commentators have criticised the common law offence as too broad and uncertain; charging with alternative, specific statutory offences has been preferred. ${ }^{14}$ For instance, prosecution authorities in England adopt a restrictive approach to bringing charges of misconduct in public office. Policy guidelines issued by the Crown Prosecution Service (CPS) state that where there is clear evidence of one or more statutory offences, those offences should be prosecuted in preference to misconduct in public office. ${ }^{15}$ When such alternative prosecutions occur, the element of 'public office' is to be regarded as constituting an aggravating factor to be taken into account in sentencing. Similarly, a United Kingdom Parliamentary Note specifically advises that while a criminal act by a public officer might result in a charge of misconduct in public office, the matter could be pursued via a criminal charge and the 'public' aspect taken into account as an aggravating factor at sentencing. ${ }^{16}$ However, for some critics even these restrictions are insufficient. Thus, Parsons believes that the scope of the offence of misconduct in public office is too broad, given the seriousness of the charge, the fact that it is triable only on indictment, and that it carries a maximum punishment of life imprisonment in the United Kingdom. He advocates a high bar for prosecution, suggesting that this offence be reserved for serious instances of misconduct when there is no alternative statutory offence that would adequately capture the nature of the misconduct or invest the court with adequate sentencing powers. ${ }^{17}$

Another response to the uncertainty has been to introduce a statutory version of the offence. For example, Queensland has introduced a statutory misconduct in public office offence. The section is modelled on the common law offence but is designed to fit more appropriately into the Criminal Code of that State. ${ }^{18}$ A statutory version of the offence has been proposed in

\footnotetext{
${ }^{13}$ See, eg, Lucinda Maer, Misconduct in Public Office (Parliamentary Note SN/PC/04909, House of Commons Library, Parliament of the United Kingdom, 2009).

${ }^{14}$ See, eg, Simon Parsons, 'Misconduct in Public Office - Should It Still Be Prosecuted?' (2012) 76(2) Journal of Criminal Law 179.

15 CPS, Misconduct in Public Office (Legal Guidance) (undated) <http://www.cps. gov.uk/legal//_to_o/misconduct_in_public_office/>.

${ }^{16}$ Maer, above n 13.

${ }^{17}$ Parsons, above n 14, 185.

${ }^{18}$ Section 92A of the Criminal Code 1899 (Qld) makes it an offence for a public officer to deal with information gained because of office, to perform or fail to perform a function of office, or to do an act in abuse of the authority of office, with intent to dishonestly gain a benefit for the officer or another person or to dishonestly cause detriment to another person. The offence
} 
England. ${ }^{19}$ However, most jurisdictions have resisted the call for codification, and misconduct in public office continues to be a common law offence.

\section{Prosecutions}

While the controversy concerning the appropriate way to prosecute behaviour constituting misconduct in public office continues, in the last quarter of the $20^{\text {th }}$ century there was an apparent increase in the number of prosecutions of the common law offence. The revival of the offence has been traced ${ }^{20}$ to two key cases in England: $R v$ Llewellyn-Jones and $R v$ Dytham. ${ }^{21}$ The former involved a county court registrar using his office to gain an improper financial advantage; the latter involved a police officer who ignored a violent confrontation that resulted in the death of a victim of the attack. Subsequently, the offence has been prosecuted in a wide variety of circumstances. In defining the scope of public office, the nature of the office has not been important; the key matter has been that the office had to be 'for the public good'. 22

In response to a question in the British Parliament, then Secretary of State for Justice Jack Straw revealed that in England between 1998 and 2007, 56 defendants had been proceeded against in situations where misconduct in public office constituted the principal offence. ${ }^{23}$ In 2007 alone, there were proceedings against 21 defendants. ${ }^{24}$ No equivalent data is available for Australia.

There is an increasing trend for misconduct in public office offences to involve the unauthorised use of information. ${ }^{25}$ In the United Kingdom, it has been noted that utilising the misconduct in public office offence provides an

carries a maximum penalty of imprisonment of seven years. The offence came into effect from 24 September 2009.

${ }^{19}$ In 1997 the Law Commission of England and Wales recommended the creation of a statutory offence of misconduct in public office. The proposal recently has been revived and is the subject of an investigation by the Commission. A final report on the matter will be published in 2016: Law Commission of England and Wales, Eleventh Programme of Reform (July 2011) 18 <www.lawcommission.justice.gov.uk/docs/lc330_eleventh_programme.pdf>.

${ }^{20}$ Parsons, above n 14, 180.

${ }^{21}$ [1979] QB 722.

${ }^{22} R$ v Lancaster and Worrall (1890) 16 Cox CC 737, 739 (Wiles J).

${ }^{23}$ Maer, above n 13, 11.

${ }^{24}$ Ibid.

${ }^{25}$ Ibid 29. 
attractive option for prosecutors when dealing with police officers who pass on confidential details from police computers. ${ }^{26}$

\section{Elements of the Offence}

Although still relatively rarely prosecuted, an apparent revival of prosecutions for misconduct in public office has prompted re-examination of the elements and application of the offence. Four recent cases - two from Hong Kong and one each from the United Kingdom and Australia - illustrate significant judicial examination and articulation of the key elements of the offence.

In a landmark case from Hong Kong - Shum Kwok Sher v HKSAR ('Shum Kwok Sher') — Mason NPJ reviewed previous authority and outlined the elements of the offence as follows:

(1) A public official;

(2) who in the course of or in relation to his public office;

(3) wilfully and intentionally;

(4) culpably misconducts himself. ${ }^{27}$

Significantly, the Court extended the ambit of misconduct to acts or omissions 'in relation to, or under colour of exercising, the office'. ${ }^{28}$

The subsequent English case $A G$ Reference No $3^{29}$ involved police officers and caused further examination of the elements of the offence. The officers were charged with gross negligence, manslaughter, and misconduct in public office relating to a victim who presented at a hospital after a fight and became aggressive and confrontational towards hospital staff. The victim was subsequently detained by police and died in the police station after he had been handcuffed and placed in a semi-face-down position, arguably suffering severe breathing difficulties. The misconduct in public office charge alleged that each police officer 'misconducted himself whilst serving as a police

${ }^{26}$ Martin Wasik, 'Computer Misuse and Misconduct in Public Office' (2008) 22(1-2) International Review of Law Computers and Technology 135, 138.

27 [2002] 5 HKCFAR 381 [84] (Mason NPJ, Li CJ, Bokhary PJ, Chan PJ, Ribeiro PJ). The facts of the case related to the improper awarding of a government contract by a public servant property manager to members of his extended family. The court considered whether the common law offence of misconduct in public office was so general as to be unconstitutional under the Hong Kong Basic Law (Constitution).

${ }^{28}$ Ibid [81].

${ }^{29}$ [2004] EWCA 868. 
officer, by wilfully failing to take reasonable and proper care of ... an arrested person in police custody'. ${ }^{30}$ At the judge's direction, the police officers were acquitted of both the manslaughter and misconduct in public office charges, on the basis in relation to the latter that there was insufficient evidence of the element of recklessness. Following the original acquittal, the AttorneyGeneral of England sought specific guidance from the Court of Appeal on the key issue: What are the ingredients of the common law offence of misconduct in a public office?

In particular, the reference addressed the issue of whether it is necessary in proceedings for an offence of misconduct in a public office for the prosecution to prove 'bad faith' and, if so, what does bad faith mean in this context? ${ }^{31}$ The Court's answers to these questions provided a statement of the key elements of the common law offence in the United Kingdom:

The elements of the offence of misconduct in a public office are:

(1) A public officer acting as such ...

(2) Wilfully neglects to perform his duty and/or wilfully misconducts himself ...

(3) To such a degree as to amount to an abuse of the public's trust in the office holder ...

(4) Without reasonable excuse or justification ... ${ }^{32}$

The Hong Kong Court of Final Appeal next considered the matter in Sin Kam Wah and Lam Chuen Ip v HKSAR ('Sin and Lam') ${ }^{33}$ in 2005, and drew on the judgment of the Court of Appeal in AG Reference No 3 to develop the elements of the offence previously considered in the Shum Kwok Sher decision.

Sin and Lam involved an off duty policeman who was found to have accepted gratuities from a nightclub owner whom he was duty bound to arrest. The court reformulated the misconduct in public office offence into five elements articulated in the following way:

\footnotetext{
${ }^{30}$ Ibid [1].

${ }^{31}$ Ibid [2].

${ }^{32}$ Ibid [61].

${ }^{33}$ [2005] HKCFAR 29. It should be noted that in his references to this case in $R v$ Quach (2010) 27 VR 310, Redlich JA referred to the defendants Sin Kam Wah and Lam Chuen Ip as 'Wah' and 'Ip' respectively. Here, the authors use the family names of the defendants: 'Sin' and 'Lam'.
} 
The offence is committed where:

(1) a public official;

(2) in the course of or in relation to his public office;

(3) wilfully misconducts himself; by act or omission, for example, by wilfully neglecting or failing to perform his duty;

(4) without reasonable excuse or justification; and

(5) where such misconduct was serious, not trivial, having regard to the responsibilities of the office and the officeholder, the importance of the public objects which they serve and the nature and extent of the departure from those responsibilities. ${ }^{34}$

The issue was subsequently considered by the Court of Appeal of Victoria in $R v$ Quach. ${ }^{35}$ In this case the Court considered a referral from a trial judge following pre-trial argument concerning a charge of misconduct in public office involving a police officer who had allegedly used his position to take advantage sexually of a vulnerable woman. The reference sought guidance on the elements of the offence. The Court reviewed the line of authority identified above and broadly endorsed the formulation of misconduct in public office by Mason NPJ in Sin and Lam. Redlich JA outlined the elements of the offence as follows:

[T]he elements of the offence are:

(1) a public official;

(2) in the course of or connected to his public office;

(3) wilfully misconduct [sic] himself; by act or omission, for example, by wilfully neglecting or failing to perform his duty;

(4) without reasonable excuse or justification; and

(5) where such misconduct is serious and meriting criminal punishment having regard to the responsibilities of the office and the officeholder, the importance of the public objects which they

\footnotetext{
${ }^{34}$ Sin and Lam [2005] HKCFAR 29 [45] (Mason NPJ). See also Prosecutions Division of the Department of Justice (Hong Kong) Criminal Appeals Bulletin, June 2005, 11-12.

${ }^{35}$ (2010) 27 VR 310.
} 
serve and the nature and extent of the departure from those objects. ${ }^{36}$

Thus, recent Victorian authority endorses the elements of the offence identified by Mason NPJ in Sin and Lam with only minor modification in relation to the nexus between the misconduct and the office, with Quach simply requiring a 'connection'.

In the remainder of this article, the elements of the offence will be explored in relation to their application to misconduct in public office by police officers. As the discussion will show, some elements have been particularly troublesome in relation to the prosecution of police officers for this offence.

\section{$1 \quad$ Public Official}

It is clear that police officers are regarded as public officials (element 1). ${ }^{37} \mathrm{~A}$ recent judgment from the United Kingdom has also made clear that the scope of 'public officials' includes police officers serving a period of suspension as well as former police officers engaged in re-employment in a part-time capacity. ${ }^{38}$ Others who work for the police, including community support officers and those in charge of computer systems, including civilian call handlers, are also regarded as public officers.

Whilst it has been settled law that prison officers are public officials for the purpose of misconduct in public office, in Cosford, Falloon and Flynn $v$ The Queen ('Cosford'), the English Court of Appeal found that three nurses who worked for the United Kingdom prison service (but who were not prison guards) were public officials. ${ }^{39}$ Interestingly, the Court held that whether the nurses were employees of a public authority or private entity was not significant in determining liability for the offence:

Whether the prison is run directly by the state or indirectly through a private company paid by the state to perform this function does not alter the public

\footnotetext{
${ }^{36}$ Ibid [46].

${ }^{37} R v$ Dytham (1979) 69 Cr App R 387; DPP v Marks [2005] VSCA 277; $R v$ Quach (2010) 27 VR 310

${ }^{38}$ Cosford, Falloon and Flynn v The Queen [2013] EWCA Civ 466 [35]. The Court of Appeal summarised an array of employment situations in which people have been judicially regarded as public officials for the purposes of misconduct in public office.

39 [2013] EWCA Civ 466. In the context of contemporary government business models, this raises a number of interesting issues for an increasingly privatised policing function and the potential for misconduct in public office to be extended to the realm of private policing.
} 
nature of the duties of those undertaking the work: the responsibilities to the public are identical. ${ }^{40}$

A recent Hong Kong Court of Final Appeal case has reiterated that the definition of public official applies to those who exercise 'powers, discretions or duties exercisable by virtue of his official position, conferred on him for the public benefit'. ${ }^{41}$ The Court noted that a person who occupies a position that confers no such powers on him 'is not a candidate for prosecution for the offence [of misconduct in public office] even if he is employed by a government department or by an analogous public body'. ${ }^{42}$

Millett NPJ summarised this position as follows:

The offence can be committed only by a public official. It cannot be committed by an ordinary member of the general public. But it does not discriminate against government employees. The reason it does not do so is that the core concept is abuse of official power. It can therefore be committed only by persons who are invested with powers, duties, responsibilities or discretions which they are obliged to exercise or discharge for the benefit of the general public. Such persons may or may not be employed by the government; they may or may not be paid. They may be high officers of state or lowly employees; the offence may be committed as well by a police or customs officer as by a government minister. The common element is that the accused must have abused some power, duty or responsibility entrusted to or invested in him or her and exercisable in the public interest. ${ }^{43}$

Thus, while not every public employee is susceptible to liability, ${ }^{44}$ police officers and a range of others exercising policing and related powers and responsibilities in the public interest clearly fall within the ambit of the offence of misconduct in public office.

\section{In the Course of or Connected to Public Office}

The second essential element in misconduct in public office is that the misconduct has a sufficient nexus to the public office. In AG Reference No 3, the Court of Appeal held that the misconduct must occur when the public official was acting as such. However, Mason NPJ appeared to adopt a broader interpretation of the relationship in the later case of Sin and Lam, holding that

\footnotetext{
${ }^{40}$ Cosford [2013] EWCA Civ 466 [37].

${ }^{41}$ HKSAR $v$ Wong Lin-Kay [2012] HKCFA 33 [19] (Ribeiro PJ) (emphasis added).

${ }^{42}$ Ibid [22].

${ }^{43}$ Ibid [44].

${ }^{44}$ Ibid [34].
} 
this element will be satisfied where the misconduct occurs 'in the course of or in relation to [the] public office'. ${ }^{45}$ In determining whether the necessary nexus was established, Mason NPJ went on to say:

To constitute the offence of misconduct in public office, wilful misconduct which has a relevant relationship with the defendant's public office is enough. Thus, misconduct otherwise than in the performance of the defendant's public duties may nevertheless have such a relationship with his public office as to bring that office into disrepute, in circumstances where the misconduct is both culpable and serious and not trivial. ${ }^{46}$

Sin and Lam suggests that a charge of misconduct in public office against a police officer may be sustained even if the officer was not actually on duty at the relevant time. Redlich JA in Quach reaffirmed this interpretation of this element in Victoria, quoting the High Court of Australia in Bunning $v$ The Queen: 'The offences having been committed by a public officer and in the purported course of his duties (or sufficiently connected with those duties)'. ${ }^{47}$ In fact, Australian jurisprudence now suggests that interpreting AG Reference No 3 as requiring a stricter relationship than was required in Shum Kwok Sher is based on a misunderstanding. Redlich JA noted in Quach that, in AG Reference No 3:

The Court of Appeal referred with apparent approval to Shum Kwok Sher, at least in respect of that particular element, and expressly adverted to the fact that the element was not in issue before them. It did not appear to recognise any difference between its conception of the element and that articulated in Shum Kwok Sher. Significantly, the later decision of Wah \& IP [sic] which restated the elements in Shum Kwok Sher, referred with apparent approval to the decision of the Court of Appeal in $A G$ No 3, which suggests that neither Court perceived any inconsistency between their differing descriptions of the element. ${ }^{48}$

\footnotetext{
${ }^{45}$ [2005] HKCFAR 29 [45] (emphasis added).

${ }^{46}$ Ibid [47].

${ }^{47}$ [2008] HCASL 267 [6] (Kirby and Heydon JJ, quoted in $R v$ Quach (2010) 27 VR 310 [35] (emphasis added by Redlich JA). In Bunning $v$ The Queen, the High Court refused to grant Bunning special leave to appeal against sentence on 10 counts of misconduct in public office. In the original Victorian County Court trial, Bunning had pleaded guilty to the misconduct in public office charges. He appealed the sentence to the Court of Appeal. In the appeal, the prosecution conceded 'an error which vitiates the exercise of the sentencing discretion' ( $R v$ Bunning [2007] VSCA 205 [3] (Kellam JA)). The appeal was allowed and the Court of Appeal re-sentenced the defendant. Bunning subsequently sought leave to appeal to the High Court but leave was not granted, and as part of their judgment, Kirby and Heydon JJ made the comments later taken up by Redlich JA, as reported here.
}

${ }^{48} R v$ Quach (2010) 27 VR 310 [36]. 
The upshot of this is that a successful prosecution may be conducted against a public official even when the relevant misconduct occurred when they were operating in an apparently private capacity - provided that there is a sufficient connection between their conduct and their public office. As Redlich JA made clear:

Certain responsibilities of the office will attach to the officer whether or not the officer is acting in the course of that office. Where the misconduct does not occur during the performance of a function or duty of the office, the offence may be made out where the misconduct is inconsistent with those responsibilities. It may be connected to a duty already performed or to one yet to be performed or it may relate to the responsibilities of the office in some other way. The misconduct must be incompatible with the proper discharge of the responsibilities of the office so as to amount to a breach of the confidence which the public has placed in the office, thus giving it its public and criminal character. ${ }^{49}$

Thus, in Quach, there is confirmation that the second element of the offence is essentially as outlined in Sin and Lam, with a refined statement of the nexus between the conduct and the office held by the public official as relating to acts or omissions 'in the course of or connected to [the] public office'. The Hong Kong and Australian judgments suggest that this is regarded as consistent with — and indeed, a clarification of - the approach in $A G$ Reference No 3.

\section{$3 \quad$ Wilful Misconduct by Act or Omission}

The third element of misconduct in public office raises two issues: (1) wilfulness and intention on the part of the public official; and (2) responsibility for acts and omissions - for misfeasance/malfeasance and nonfeasance. In relation to the latter, it has been established that nonfeasance (failure to act) as well as misfeasance (wilful or intentional inappropriate or incorrect action) and malfeasance (wilful or intentional action that causes injury), can found a prosecution (element three). Nonfeasance was the basis of misconduct in the English case of $R v$ Dytham. In this case, a police officer on duty and in uniform - failed to intervene in a violent assault to which he was a witness (and the victim died as a result of the assault). The officer was charged with, and found guilty of, misconduct in public office. The trial judge commented:

the accused misconducted himself whilst acting as an officer of justice in that he, being present and witness to a criminal offence, apparently a violent assault ... deliberately failed to carry out his duty as a police constable by

\footnotetext{
${ }^{49}$ Ibid [40] (Ashley JA and Hansen AJA).
} 
wilfully omitting to take any steps to preserve the Queen's Peace or to protect the person ... or to arrest or otherwise bring to justice [the] assailants. ${ }^{50}$

Misconduct in public office was established in this case on the basis of a deliberate and knowing failure to act, construed as a wilful neglect of duty.

$R v$ Dytham also provides some insight into the issue of wilfulness. The defence had argued that misconduct in public office required evidence of 'some improper or corrupt or dishonest motive' and that nonfeasance by the holder of a public office was insufficient to establish liability for the offence; there must, it was argued, be malfeasance or at least misfeasance involving an element of corruption. ${ }^{51}$

However, both the trial judge and the appeal court found that the offence could be found 'in circumstances where there is no element of corruption or dishonesty'. ${ }^{52}$ The appellate court found that, although prior judgments showed that many misconduct in public office cases did involve a dishonest motive:

[S]ome corrupt taint ... [is] not a necessary incident of the offence. Misconduct in a public office is more vividly exhibited where dishonesty is revealed as part of the dereliction of duty. Indeed in some cases the conduct impugned cannot be shown to have been misconduct unless it was done with a corrupt or oblique motive. ${ }^{53}$

The court identified that the key test was whether 'the misconduct impugned is calculated to injure the public interest so as to call for condemnation and punishment'. 54

A more recent test of these elements arose in the United Kingdom in the 2010 appellate decision in $R v W^{55}$ where a metropolitan police officer misused a police-provided credit card for personal expenditures. The parameters of the card provided to the officer covered legitimate travel and subsistence in relation to official duties. He failed to submit expense summaries and appropriate forms and admitted to using the card contrary to Force

\footnotetext{
${ }^{50} R v$ Dytham (1979) 69 Cr App R 387, 389 (Neill J).

${ }^{51}$ Ibid.

${ }^{52}$ Ibid 391 (Neill J).

${ }^{53}$ Ibid 393 (Shaw LJ, Widgery LCJ and McNeill J) (emphasis added).

${ }^{54}$ Ibid 394. The judge added: 'Whether such a situation is revealed by the evidence is a matter that a jury has to decide. It puts no heavier burden upon them than when in more familiar contexts.'

${ }^{55}$ [2010] EWCA Crim 372.
} 
instructions. However, the defence argued that: he intended to repay the private expenditure amounts; the practice of using and then repaying the Force was common practice amongst his colleagues; and, whilst he had wilfully misused the card, he was not guilty of deliberate dishonesty or misconduct.

The police officer had been convicted at the Crown Court at Southwark in 2009. The trial judge had provided directions to the jury with regard to the proof that was required to establish the offence of misconduct in public office:

The jury was directed that the prosecution had to prove that the appellant 'wilfully — that means to say, deliberately — misconducted himself to such a degree as to amount to an abuse of the public's trust in that office holder, without reasonable excuse or justification. ... the prosecution must prove misconduct of a high degree. We are not talking here about a mere bending of the rules or cutting corners ... to amount to abuse of public trust a mistake, even a serious one, will not suffice either. The prosecution must prove that the office holder has fallen way below, or far below, the standards expected of him as, in this case, a police officer'. ${ }^{56}$

This direction was the subject of a successful appeal to the Court of Appeal: the appellant argued that the original trial judge had erred in law. Cronin argues that this direction as far as it went was consistent with AG Reference No 3 but that the trial judge favoured the Crown's submission that no particular subjective mental element was required. ${ }^{57}$ This seemed to overlook the statement in AG Reference No 3 that:

There must be an awareness of the duty to act or a subjective recklessness as to the existence of the duty. The recklessness test will apply to the question whether, in particular circumstances, a duty arises at all as well as to the conduct of the defendant if it does. The subjective test applies both to reckless indifference to the legality of the act or omission and in relation to the consequences of the act or omission. ${ }^{58}$

In relation to dishonesty, the Court of Appeal found that:

when the crime of misconduct in a public office is committed in circumstances which involve the acquisition of property by theft or fraud, and in particular when the holder of a public office is alleged to have made improper claims for public funds in circumstances which are said to be

\footnotetext{
${ }^{56}$ Ibid [7] (Penry-Davey LCJ and Irwin J).

57 Alison Cronin, 'Misconduct in Public Office: Dishonesty Is an Element if Misconduct Amounts to Theft or Fraud' (2010) 74(4) Journal of Criminal Law 290, 290.

${ }^{58}$ [2004] EWCA 868 [30].
} 
criminal, an essential ingredient of the offence is proof that the defendant was dishonest. ${ }^{59}$

Cronin criticised the reasoning of the Court of Appeal on this issue, arguing that it was based on a selective reading of the older cases, in particular $R v$ Dytham. ${ }^{60}$ Cronin argues that the Court relied on an observation made in Dytham that the offence of misconduct 'is not restricted to dishonesty', ${ }^{61}$ extrapolating a 'clear implication that dishonesty would be a necessary ingredient of some manifestations of the offence'. ${ }^{62}$ According to Cronin:

It would seem this innocuous, uncontroversial comment in Dytham acknowledging the broad nature of the offence, is now taken by the Court of Appeal as authority for the proposition that dishonesty will be a necessary element of the offence in some circumstances. ${ }^{63}$

The problem as Cronin sees it is that this now blurs the historical distinction between two separate lines of cases relating to nonfeasance and misfeasance. She sees this as crucial to an understanding of the offence, at least in the United Kingdom. Relying on the early case of $R v$ Bembridge, she identifies the need for proof that the concealments were made corruptly and fraudulently and argues that this mens rea requirement was followed in subsequent cases of positive misfeasance.

In other cases which emerged around the same time, an alternative branch of misconduct in public office was developed that recognised its existence in the neglect of official duties or 'nonfeasance'. Unlike misconduct by misfeasance, misconduct by nonfeasance did not require mens rea. The importance of this difference between the two branches of the offence is that the failure to clearly separate the two resulted in some confusion as to when the subjective mental element of corruption, dishonesty or oppression must be proven. Cronin argues that AG Reference No 3 unified the offence, incorporating both misfeasance and nonfeasance and imposing a subjective mental element to both types of behaviour. So, based on AG Reference No 3, misconduct in public office involves wrongdoing that amounts to an abuse of public trust and 'wilful misconduct' means 'deliberately doing something which is wrong

\footnotetext{
${ }^{59} R v W$ [2010] EWCA Crim 372 [14].

${ }^{60}$ Cronin, above n 57, 291.

${ }^{61} R v$ Dytham (1979) 69 Cr App R 387, 394.

${ }^{62} R v W$ [2010] EWCA Crim 372 [10].

${ }^{63}$ Cronin, above n 57, 292.
} 
knowing it to be wrong or with reckless indifference as to whether is it wrong or not'. ${ }^{64}$

The point here is that the relevant mental state may or may not be accompanied by dishonesty. If present, dishonesty may aggravate the offence, but, according to Cronin's analysis of $A G$ Reference No 3, it is no longer a necessary ingredient in misconduct. Misconduct and dishonesty are separate and distinct concepts. This leads to Cronin's criticism of the decision in $R v W$, where the court reintroduced a requirement that dishonesty be proved in any misconduct case that involved theft or fraud. In summary, notwithstanding Cronin's critique, it may be noted that in $R v W$ the Court found that:

depending on the acts and omissions alleged, the mental element of the offence will vary ... Accordingly the nature of the conduct falling within the ambit of the offence is very wide, and logically it would follow that any necessary element relating to the defendant's subjective state of mind cannot be identical for each and every one of its different manifestations. ${ }^{65}$

Thus, in some cases, the case law suggests that it will be insufficient - in order to establish the offence of misconduct in public office - to simply demonstrate that the relevant conduct or omission occurred and that the defendant acted intentionally. Evidence may be required of dishonesty or deceit, or, at least, a subjective awareness or appreciation of the consequences that would likely flow from the act or omission.

\section{Reasonable Excuse or Justification}

$R v$ Dytham demonstrated the requirement of sufficient connection between wilfulness and lack of excuse of justification. The judge found that:

The neglect must be wilful and not merely inadvertent; and it must be culpable in the sense that it is without reasonable excuse or justification ... The allegation made was not of mere non-feasance but of deliberate failure and wilful neglect ... This involves an element of culpability. ${ }^{66}$

\footnotetext{
${ }^{64}$ Cronin, above $\mathrm{n}$ 57, 293. These words draw on a comment from AG Reference No 3 [2004] EWCA Crim 868 [28] that: '[W]ilful misconduct means "deliberately doing something which is wrong knowing it to be wrong or with reckless indifference as to whether it is wrong or not". That statutory construction has been approved by the Court of Appeal and the House of Lords.' However, it should be noted that the AG Reference No 3 ruling went on to say: 'We regard that direction as helpful in present circumstances, considering as we do that the concept of wilful misconduct is apt to the offence of misconduct in public office.'

${ }^{65}$ [2010] EWCA Crim 372 [8].

${ }^{66}$ (1979) 69 Cr App R 387, 394 (Shaw LJ, Widgery LCJ and McNeill J).
} 
Together, the third and fourth elements of the offence relate to the determination of a public official's culpability for the relevant act or omission. Beyond this, the requirement that the misconduct occur 'without reasonable excuse or justification' (element 4) may best be regarded as a defence, rather than an element of the offence per se.

\section{$5 \quad$ Seriousness of the Misconduct}

In $R v$ Quach, the Victorian court was asked to consider the question of the seriousness of the misconduct. In arriving at the formulation of the fifth element of the offence, the court followed the approach adopted in Shum Kwok Sher and then Sin and Lam. The misconduct must be 'serious having regard to the responsibilities of the office and the officeholder, the importance of the public objects which they serve and the nature and extent of the departure from those objects'. ${ }^{67}$

Redlich JA, however, noted that although AG Reference No 3 'endorsed the condition that the "serious departure from proper standards ... must be so far below acceptable standards as to amount to an abuse of the public's trust in the office holder", I do not regard this to be part of the definition of the offence although it serves to emphasise the degree of departure from the proper standard that must be established'. ${ }^{68}$ Thus, the formulation of 'seriousness' in Quach does not require misconduct sufficient to constitute an abuse of office but requires non-trivial misconduct assessed within the context of the responsibilities of the public office holder and the departure from it.

\section{E Incidental Offences}

Parsons has identified multiple problems with those modern cases in England dealing with misconduct in public office. He argues that: conduct that does not involve actual misconduct in public office has been prosecuted where the conduct was merely incidental to the public office; the elements of the crime are uncertain; and specific alternative crimes can, and should, be prosecuted instead. ${ }^{69}$ Focusing on two English cases central to the revival of the offence ( $R \vee$ Llewellyn-Jones and $R \vee$ Dytham), he argues that the facts of each of these cases show the breadth of crimes to which misconduct in public office may be applied. The former case involved a County Court registrar using his

\footnotetext{
${ }^{67} R v$ Quach (2010) 27 VR 310 [43]. Redlich JA noted that both counsel for the accused and the Crown accepted that this formed part of the offence.

${ }^{68}$ Ibid [44].

${ }^{69}$ Parsons, above n 14, 180.
} 
office to gain an improper financial advantage (the registrar having used public moneys paid into a court to fund his private mortgage debt); the latter case involved an on-duty police officer who ignored a violent confrontation that resulted in the death of a victim of the attack. Parsons suggests that in each of these cases more specific charges (such as 'fraud by abuse of position' and 'killing by gross negligence' respectively) would have been more appropriate than misconduct in public office. ${ }^{70}$ Commenting on $R \quad v W$, Parsons argues:

this was not a case of misconduct in a public office as W's misconduct did not take the form of a breach of, or failure to perform his duties, as a police officer. W should have been charged with theft or, if there had been a false representation, fraud. ${ }^{71}$

Spencer ${ }^{72}$ has also offered a critique of the application of misconduct in public office to what he regards as incidental offences. Commenting on $R v$ $W$, Spencer argues that misconduct in public office 'should not cover what the detective did [in $R v W$ ], even if "dishonesty" was present' ${ }^{73}$ He makes the point that the essence of the crime of misconduct in public office is either wilful neglect of entrusted public duties or wilful abuse of office for some improper end, arguing that the scope of the crime should have a restricted ambit such that it ought not to cover the incidental commission of another crime 'as might be committed by any dishonest employee'. Spencer suggests, instead, that the status of police officer 'might be thought to aggravate the sentence for the fraud offence'. ${ }^{74}$ In summary, Spencer believes that misconduct in public office offences should be limited to the improper exercise of the public function and should not extend to behaviour merely incidental to it such as the making of fraudulent expense claims.

The problem with the analyses of both Spencer and Parsons is that they fail to fully address the breach of the public trust inherent in misconduct in public office offences. The positions of the two authors may be arguable in the case of theft or fraud that occurs in the context of an offence against a private corporation. In such circumstances, the crimes of theft, false representation or fraud may be regarded as adequately encapsulating the wrongdoing. On the other hand, in the public realm, where action is pursuant to a public mandate and reliant on, and in the name of, the public trust, an additional dimension of

\footnotetext{
${ }^{70}$ Ibid 180 .

${ }^{71}$ Ibid 184.

72 J R Spencer, 'Policemen Behaving Badly - The Abuse of Misconduct in Public Office' (2010) 69(3) Cambridge Law Journal 423.

${ }^{73}$ Ibid 423.

${ }^{74}$ Ibid 423-4 (emphasis added).
} 
the breach is arguably not captured by the 'head' offence. Specifically, police officers must be held to a high standard and where a public official, paid from the public purse, engages in behaviour within the very organisation that is tasked with investigating such crimes on behalf of the public, that public trust is itself breached and offended.

There may be factual scenarios where it is merely incidental that the person is a police officer, and charging decisions in such cases should reflect this. However, as the subsequent discussion of recent cases demonstrates, the public interest is served in charging a police officer with the specific behaviour-relevant charge (for example, sexual assault or rape, trafficking in or possession of drugs, theft, bribery or extortion) and requiring the offender to face a charge that is directly related to the holding of public office and breach of behavioural expectations attached to that office. The offence of misconduct in public office arguably captures this element of the misconduct in a way that the more specific criminal charges do not.

\section{Breach of Trust: Contemporary Cases}

\section{A Disclosure of Confidential Information}

Police officers are privy to sensitive, confidential information in relation to the investigation and prosecution of crime. Occasionally, a police officer may disclose such information to parties outside the police force, without authorisation. Disclosure may be motivated by personal gain ${ }^{75}$ or a desire to benefit criminal acquaintances. ${ }^{76}$ Such disclosures may give rise to many forms of liability, ${ }^{77}$ including prosecution for misconduct in public office.

In the 2005 case of DPP $v$ Marks, ${ }^{78}$ the misconduct in public office charge (one count) was coupled with drug use and possession charges (two counts) relating to the drug ecstasy. At trial the police officer pleaded guilty to all charges. Without imposing a conviction, the judge imposed a fine of $\$ 4000$ on the misconduct in public office charge and $\$ 300$ and $\$ 50$ respectively in relation to the drug charges. The Director of Public Prosecutions (DPP)

\footnotetext{
${ }^{75}$ See $R$ v Casburn (Unreported, Southwark Crown Court, Fulford J, 1 February 2013) $<$ http://www.judiciary.gov.uk/wp-content/uploads/JCO/Documents/Judgments/april-casburnsentencing-remarks-01022013.pdf $>$.

${ }^{76}$ DPP v Marks [2005] VSCA 277.

${ }^{77}$ Interestingly, in DPP v Artz [2013] VCC 56, a police officer who disclosed confidential information to a journalist was prosecuted under s 127A(1AB) of the Police Regulations Act 1958 (Vic) rather than for misconduct in public office (see below $n$ 126).

${ }^{78}$ [2005] VSCA 277.
} 
appealed against the sentence. The key claim was that, in failing to record a conviction and imposing the specified fines, the judge had failed to give appropriate weight to relevant sentencing considerations and had placed too much weight on mitigating factors. ${ }^{79}$ The DPP focused on the seriousness of the offence, the need for general deterrence of other police officers and public officials, the breach of trust involved, and the damage to public confidence associated with the offence. ${ }^{80}$

A key issue for the Court of Appeal, and an impediment to a successful appeal by the DPP, was the unchallenged failure of the judge to make findings that the police officer's conduct was anything more than an error of judgment. The DPP's appeal was against the original sentence imposed but not against the County Court findings, thus binding the Court of Appeal to the findings of the trial judge. ${ }^{81}$

The relevant facts underpinning the misconduct charge, as reported in the Court of Appeal judgment, were that the police officer accessed a confidential police database and obtained information which he subsequently passed on to a drug trafficker (who was the subject of a major drug investigation), relating to a friend of the drug dealer who had been intercepted and arrested for possessing 300 ecstasy tablets. This information was accessed in response to the drug trafficker having requested it, and the information was conveyed over the phone by the police officer. The matter was identified as a result of a telephone intercept that was in place at the time. The disclosure of confidential information in the telephone conversation and the accessing of the confidential database formed the basis of the charges of misconduct in public office.

In his defence, the police officer had said that he had known the drug trafficker for 10 years through his football club and, whilst the trafficker was 'not a really good mate', the officer had given him the information 'because he was a friend of mine and he was inquiring as to what ... [had] happened to one of his friends'. ${ }^{82}$ The Crown accepted that the police officer believed the drug trafficker was only 'low level' and also accepted that police investigations had not been impeded by the police officer's actions. ${ }^{83}$

In summarising the initial sentencing judge's reasoning, Eames $\mathrm{J}$ noted that the trial judge viewed the police officer's behaviour as an error of judgment

\footnotetext{
${ }^{79}$ Ibid [3].

${ }^{80}$ Ibid [4].

${ }^{81}$ Ibid [28] (Nettle J), [32] (Buchanan J).

${ }^{82}$ Ibid [10].

${ }^{83}$ Ibid [12].
} 
rather than a display of moral turpitude, and that he had believed that the police officer acted because of his gregarious nature and the value placed by him on friendship and loyalty. Eames $\mathrm{J}$ believed that the trial judge relied on those characteristics to explain why the officer might have succumbed to what appeared to the officer to have been 'a relatively innocent transfer of information'. ${ }^{84}$

The Court of Appeal was highly critical of this reasoning, with Nettle $J$ describing it as 'fanciful' to believe that 'the provision of criminal intelligence to a known drug dealer' could be regarded as a 'relatively innocent transfer of information'. ${ }^{85}$ On the contrary, Nettle $\mathrm{J}$ stated that 'it was a serious offence'. ${ }^{86}$

Notwithstanding these remarks, the Court of Appeal was confined by the formal basis of the appeal. Although the finding of the original court was described as 'remarkably generous', with evidence described as 'point[ing] very clearly to the opposite conclusion', the Court was 'bound by the finding made' because an appeal must be 'strictly confined by the terms of the Notice of Appeal' ${ }^{87}$ Counsel for the DPP made it clear to the Court that the sentence was the DPP's key concern. ${ }^{88}$ Despite this, Nettle J noted:

Were it not for the way in which the matter was conducted before the sentencing judge and on this appeal, I have no doubt that the respondent should have been convicted of the offence of misconduct in public office, and that the seriousness of the offence would have warranted a term of imprisonment. ... However it is not now open to rectify the position. ${ }^{89}$

The appeal was dismissed, but the Court made a number of key points relating to the scope and relevance of the offence. Interestingly, Counsel for the DPP argued that the original trial judge seemed to believe that, by virtue of the police officer having to answer a prosecution in the County Court, this was sufficient punishment to amount to general deterrence. She pointed out that misconduct in public office is an indictable offence and the fact that the prosecution was brought in the County Court rather than the misconduct being made the subject of prosecution for unauthorised disclosure of information in

\footnotetext{
${ }^{84}$ Ibid [18].

${ }^{85}$ Ibid [33].

${ }^{86} \mathrm{Ibid}$.

${ }^{87}$ Ibid [29] (Eames J).

${ }^{88}$ Ibid [22]. The Appeal Court noted that there had been no contention by the Crown that the count should result in imprisonment (suspended or not) (at [21]). Counsel for the DPP conceded that if the original fine had been higher for the misconduct in public office, perhaps $\$ 20000$ (even without conviction), the DPP might not have appealed at all (at [22]).

${ }^{89}$ Ibid [37] (Nettle J).
} 
the Magistrates' Court under section 127A of the Police Regulation Act reflected the seriousness of the offence but should not be regarded as punishment in itself. ${ }^{90}$ This point received strong support from Nettle J when he said:

[T]here is throughout the learned sentencing judge's remarks an idea that the respondent was somehow harshly dealt with by being charged with an indictable offence of misconduct in public office, rather than being dealt with summarily under the Police Regulation Act 1958. Rightly or wrongly, I gain the impression also that his Honour's sentencing disposition may have been informed by some such notion. Such a notion would be misconceived. ${ }^{91}$

Nettle J went on to clearly articulate the importance and utility of the offence of misconduct in public office both in general terms and in circumstances such as DPP v Marks:

Unlike the narrower offences of bribery and extortion, the offence of misconduct in public office is not primarily concerned with abuse of position for pecuniary gain, but rather, as a common law offence, it gives expression to principles attributed to Lord Mansfield: that a man accepting an office of trust concerning the public is answerable criminally to the Crown for misbehaviour in the office; and that, whereas breach of trust, fraud and imposition in a matter concerning the public is as between individuals only actionable, between the Crown and the subject it is indictable. The object is to ensure that an official does not, by any wilful act or omission, act contrary to the duties of his office; does not abuse intentionally the trust reposed in him. ${ }^{92}$

His Honour found that Marks had accepted an office of trust by virtue of his appointment as a constable and that he had abused that trust when he knowingly passed on information despite being aware of his duty to maintain the confidentiality of information held on the police database. The fact that the information passed on concerned the arrest of a man the police officer knew to be a drug trafficker resulted in an appropriate indictment for misconduct in public office.

It should be noted that in Victoria the common law offence of misconduct in public office carries a maximum penalty of 10 years' imprisonment ${ }^{93}$ whereas

\footnotetext{
${ }^{90}$ Ibid [26].

${ }^{91}$ Ibid [34].

${ }^{92}$ Ibid [35].

${ }^{93}$ Crimes Act 1958 (Vic) s 320.
} 
in the United Kingdom the sentence is at the discretion of the court (and theoretically can be anything up to life imprisonment).

\section{B Misrepresentation of Office}

In 2007 in DPP $v$ Armstrong ${ }^{94}$ the Victorian DPP again appealed a sentence involving a police officer who had pleaded guilty to three counts of misconduct in public office, two counts of theft, and one count of trafficking in a drug of dependence. All counts arose out of separate transactions between the police officers, two cannabis growers and an unregistered informant of a junior colleague of Armstrong (Johnson). Armstrong was sentenced to various terms of imprisonment for the offences, ranging from one to 12 months' imprisonment - all to be served concurrently. ${ }^{95}$ The net result was a total effective sentence of 12 months' imprisonment, eight months of which was suspended for two years. ${ }^{96}$

Armstrong had told the trial court that he had felt pressured to commit the offences by his co-offender (Johnson). According to the evidence, as reported in the Court of Appeal judgment, Armstrong knew that his colleague was in financial trouble and he suspected that Johnson wanted him to accompany Johnson to the home of a cannabis grower. Armstrong acknowledged that he was aware that the purpose of the visit was 'to get information for [Johnson] and not for the job ... he wanted to make money for himself, his financial gain'. ${ }^{97}$ Armstrong said that he accompanied Johnson out of an obligation to see that he was all right, but not to help him financially.

The two police officers attended the home of the cannabis grower. Prior to the visit they had signed on at the police station (although they were not rostered for duty) and had signed out firearms and other equipment before going to the victim's residence in an unmarked police car. On arrival at the house they identified themselves as police officers and Johnson purported to have a search warrant that he showed to the victim. Armstrong knew that no search warrant had been issued and that the victim had only very limited English. The guns of both police officers were visible.

The first count of misconduct in public office was based on Armstrong unlawfully gaining entry to the premises of the victim by allowing Johnson to

\footnotetext{
94 [2007] VSCA 34.

${ }^{95}$ Ibid [18]-[20].

${ }^{96}$ Ibid [21].

${ }^{97}$ Ethical Standards Department interview quoted in ibid [5].
} 
state that he had a search warrant. ${ }^{98}$ The police officers searched the premises, found 18 cannabis plants and heat lamps that they removed into their own possession (this conduct leading to the first count of theft).

Whilst in the house and in the presence of Armstrong, Johnson asked the victim if he had any money and indicated that if he paid he would have no further trouble. The victim said that he did not have money but that he would borrow some. After leaving the house, the two police officers then contacted their initial informant (who had provided the information about the victim) to ask where they could dry out the cannabis. They went to a property to which they were directed by the informant and placed the plants in a shed to dry out. Johnson and the victim discussed splitting the proceeds three ways (this conduct leading to a charge of trafficking in a drug of dependence). ${ }^{99}$

Later that evening there were a number of telephone calls between the victim and Johnson as to whether the promised money had been obtained. A meeting was agreed upon. The victim and the two police officers arrived at the meeting in their respective cars. While Armstrong remained in his car, Johnson accepted the handover of $\$ 8000$ in the other car. Although Armstrong had no contact with the victim on this occasion, he was aware of events and did not prevent the extortion. The second count of misconduct in public office related to this behaviour. ${ }^{100}$

The next day Johnson told Armstrong that the cannabis crop was missing and that police had seized it. Both went to visit the victim to make sure that he had not spoken to other police. A few days later Armstrong made inquiries with the Asian squad regarding the discovery of a marijuana crop but he did not reveal that he knew anything about the matter. About a week later Johnson was interviewed by the Ethical Standards Department. He claimed that he had seen the cannabis and planned to make further inquiries and execute a search warrant. Armstrong provided a statement to the Ethical Standards Department that confirmed Johnson's version of events. ${ }^{101}$ About a month later, Armstrong was arrested and initially "made a "no comment" record of interview'. ${ }^{102}$ However, in a subsequent interview he admitted the theft of cannabis, admitted taking it to the farm to dry it out, but denied any plan to split the money three ways with the victim and Johnson.

\footnotetext{
${ }^{98}$ Armstrong initially received a sentence of imprisonment for one month on this count.

${ }^{99}$ [2007] VSCA 34 [10].

${ }^{100}$ Ibid [11]. Armstrong initially received a sentence of imprisonment for 12 months on this count.

${ }^{101}$ Ibid [12].

${ }^{102}$ Ibid [13].
} 
The final count of misconduct in public office related to a separate incident involving a similar modus operandi. Both police officers had again visited a property where cannabis was being grown and trafficked; again a document was presented which purported to be a search warrant and the police officers seized and removed 20 cannabis plants. The seizure of this crop was not recorded or entered in a police property log. ${ }^{103}$ The false representation regarding the search warrant resulted in the third count of misconduct in public office, and the seizure of the cannabis was the subject of a further theft charge. $^{104}$

At trial, the judge found that it was Johnson who had initiated the offences and that Armstrong had just gone along with him. He also found that Armstrong knew that 'Johnson was a police officer who, at the very least, was prepared to cut corners, was high-handed, and was prepared to do things which could jeopardise successful prosecution'. ${ }^{105}$ The Court of Appeal noted that the initial trial judge took account of the seriousness of the offending when he said:

Corruption in the police force can only flourish if decent officers turn a blind eye to it. Every corrupt or wayward member of the Victorian Police Force must understand that if they abuse their powers or cross over to the other side of the law the courts will see that they face the humiliating and degrading experience of sharing prison with common criminals, onerous as that may be for them. ${ }^{106}$

The DPP appealed against the individual sentences, the head sentence, and the extent of the order for partial suspension, on the ground of manifest inadequacy. In particular, the gravity of the three counts of misconduct in public office and their importance to the concept of general deterrence were highlighted. The DPP argued that insufficient weight had been given to factors that aggravated Armstrong's blameworthiness, including the fact that he held a senior rank to Johnson and that the offences involved serious breaches of trust.

The Court of Appeal considered whether partial suspension of sentence was warranted in light of the circumstances of the case. The Court held that, whilst the trial judge had acknowledged the serious consequences of police misconduct, the sentences imposed in relation misconduct in public office:

\footnotetext{
${ }^{103}$ Armstrong initially received a sentence of imprisonment for one month on this count.

${ }^{104}$ DPP v Armstrong [2007] VSCA 34 [14].

${ }^{105}$ Ibid [16].

${ }^{106}$ Ibid [17] (Neave JA, Vincent JA and Kellam AJA).
} 
do not adequately reflect the gravity of these offences ... The respondent was sentenced to only one month's imprisonment on each of the counts involving illegal entry on to premises and to only one year's imprisonment on the count covering the extortion of money from [the victim] in return for not reporting the presence of cannabis. ${ }^{107}$

The Court noted that 'police are in a position to exercise considerable power over others. The respondent's behaviour seriously abused that power' ${ }^{108}$ After the misconduct came to light, Armstrong continued to lie to the Ethical Standards Department. On the issue of corruption the Court noted:

Corruption in those responsible for enforcing the law has significant social consequences. ... [I]t may undermine public confidence in the police force, erode the morale of honest police officers and encourage other police to turn a blind eye to similar behaviour. The community is entitled to rely on the integrity of members of the police force in investigating and prosecuting offenders. $^{109}$

The Court of Appeal went on to note that the temptation for police to extort money or abuse power is likely to be considerable when they are dealing with criminals because criminals are unlikely to report corruption through fear that this will reveal their own involvement in offending:

For this reason corrupt practices in dealing with criminals may be even more insidious than the corruption which affects honest members of the community, who are more likely to report police attempts to extort money from them. Sentences imposed for such offences must reflect public denunciation of the behaviour of the offender and deter other police from committing similar offences. General deterrence must therefore be given significant weight in sentencing a member of the police force for offences involving corruption or extortion. ${ }^{110}$

Whilst the court did take into account a number of mitigating factors raised at the initial trial, the judges nevertheless said that:

the sentences imposed by his Honour in relation to the three counts of misconduct in public office did not adequately reflect the gravity of the offences and gave too much weight to mitigating factors.... If it were not for the limitations imposed by the need to take account of the double jeopardy principle, I would have been inclined to impose a much higher

\footnotetext{
${ }^{107}$ Ibid [31].

${ }^{108}$ Ibid [32].

${ }^{109}$ Ibid [34].

${ }^{110}$ Ibid [35].
} 
sentence for count 4 , which was the most serious of the counts involving misconduct in public office ${ }^{111}$

In summary, the Court of Appeal increased the two separate one-month sentences to six months each. It imposed a sentence of two years' imprisonment for the extortion related misconduct for which Armstrong had previously been given one year. These sentences, along with the sentences for the other offences which remained unchanged, were all to be served concurrently. This created a total effective sentence of two years with one year of the sentence suspended (for an operational period of two years). ${ }^{112}$

This case demonstrated that the Court of Appeal considered the misconduct in public office charges as serious, constituting a separately identifiable aspect of the wrongdoing, and warranting separate attention by the Court.

\section{Misconduct by Off-Duty Sexual Activity}

In $R v$ Quach, previously discussed, the Court of Appeal was asked to consider the elements of misconduct in public office on a referral on a point of law. The Court provided a comprehensive analysis. The facts giving rise to the charge of misconduct in public office involved sexual activity by a police officer. Whilst the engagement of on-duty police officers in sexual activity had previously resulted in liability for misconduct in public office, ${ }^{113}$ what was unusual about Quach was that the sexual relationship had occurred while the officer was off duty. Consequently, a key aspect of the case was the establishment of a sufficient nexus between the 'public office' and the offence.

As recounted in the Court of Appeal judgment, whilst on duty and in the company of other police officers, the defendant attended at the apartment of a young woman, to make a welfare check (as she had recently attempted suicide). Later that day, when off duty, he returned to the apartment with some groceries. The young woman was at home and she was aware that Quach was a police officer. The Crown alleged that, at his suggestion, they went back to his apartment, where she showered, changed her clothes and walked on his back to relieve back pain. The Crown further alleged that at this

\footnotetext{
${ }^{111}$ Ibid [36]-[37].

112 Ibid [37]-[38].

113 See, eg, 'Diplomatic Protection Officer Jailed for Sex on Duty', BBC News London (online), 18 March 2013 < http://www.bbc.com/news/uk-england-london-21832148>; 'Police Worker Peter Bunyan Jailed over Misconduct', BBC News Cornwall (online), 19 March 2013 $<$ http://www.bbc.com/news/uk-england-cornwall-21848519>.
} 
point sexual activity occurred. (The defence denied this.) Later they returned to the young woman's apartment. ${ }^{114}$

The offence of misconduct in public office related to the allegation that Quach had wrongfully used his public office (or knowledge obtained in that office) to procure sexual penetration of a person suffering from bipolar disorder and known to him to be at risk of committing suicide, even though that conduct did not occur in the performance of his duty. The defence argued that he did not use his position or knowledge to take advantage of the person, that no sexual activity occurred and that he did not know of the state of the victim's mental health. Alternatively, the defence argued that the sexual activity had not occurred whilst Quach was acting as a police officer and therefore an element of the offence could not be made out. ${ }^{115}$

The findings of Redlich JA in Quach make clear that liability for misconduct in public office is not restricted to a police officer who is on duty; the requirement is that there must be 'a sufficient connection to their public office'. ${ }^{116}$ This will very much turn on the individual facts of each case. The problematic conduct must also be 'so far below acceptable standards as to amount to an abuse of the public's trust in the office holder' and 'sufficient to attract criminal punishment'. ${ }^{117}$ In Quach, the Court found that both requirements were satisfied.

\section{Discussion ANd ConcLusion}

A number of police services in England and Australia have pursued the implications of the public standards discussion for their internal police ethics standards. This usually relates to expectations that police will exercise their powers and discretion to the highest standards of competence, fairness and honesty. On occasion, police do not meet these standards and the aberrant behaviour is deemed too serious for the internal discipline systems. In addition to specific criminal charges following misconduct, we are now witnessing the resurgence of the offence of misconduct in public office.

The detailed case discussion above provides practical illustrations of the various manifestations of misuse of police power and authority. The cases illustrate the level of seriousness required for an offence to attract a criminal sanction beyond the summary level provided for by the legal regulatory

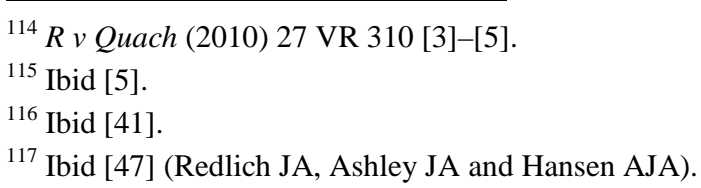


framework governing police (such as the Police Regulation Act 1958 (Vic)) or by other summary offences. They also illustrate the connection required between the public office and the misconduct for these breaches to constitute misconduct in public office.

The CPS in England appears to favour strictly confining the offence, commenting in its guidelines that where there is clear evidence of one or more statutory offences, they should form the basis of the prosecution, with the element of 'public office' providing an aggravating factor to be considered in sentencing. ${ }^{118}$ In England, the guidelines support charging the accused with a specific statutory offence in preference to using the common law offence of misconduct in public office. English courts have endorsed this approach. ${ }^{119} \mathrm{In}$ specific commentary and advice on charging practice, a United Kingdom Parliamentary Note comments that an assault by a police officer could arguably result in a misconduct in public office charge. However, an assault charge would also provide the court with the appropriate sentencing powers, with the misconduct by a public officer (the police officer) providing the aggravating factor to be considered in sentencing. ${ }^{120}$ Legal commentators in England have argued that the common law offence is too broad and that alternative statutory offence charges should be pursued in preference. ${ }^{121}$

In Australia, the DPP in each jurisdiction has significant discretion in relation to charging decisions and the discretion to prosecute is not subject to judicial review. ${ }^{122}$ Although all state and territory DPPs have issued publicly available guidelines that govern the exercise of prosecutorial discretion generally, no guidelines have been published that indicate how the discretion is to be exercised in relation to prosecuting misconduct in public office. It is clear that significant misconduct by police is also being prosecuted under statutory provisions such as section 127A of the Police Regulation Act 1958 (Vic). ${ }^{123}$ The publication of guidelines by prosecution authorities in Australia, similar to those developed by the CPS in England, would be helpful in establishing the circumstances in which the common law offence is likely to be prosecuted. In the meantime, the current review of selected cases provides some guidance as to the prosecution of misconduct in public office in Australia.

\footnotetext{
${ }^{118}$ CPS, above n 15 .

${ }^{119}$ See AG Reference No 3 [2004] EWCA Crim 868; R v Dunn (2003) 2 Cr App R (S).

${ }^{120}$ Maer, above n 13.

${ }^{121}$ For example Parsons, above n 14.

${ }^{122} R$ v McCready (1985) 20 A Crim R 32, 39; Chow v DPP (NSW) (1992) 28 NSWLR 593, 604-5; Maxwell $v$ The Queen (1996) 184 CLR 501.

${ }^{123}$ For example, see DPP v Artz [2013] VCC 56.
} 
In the matter of DPP $v$ Marks, the key misconduct related to the disclosure of confidential information from a confidential police database to a drug trafficker about an associate, both of whom were the subjects of ongoing investigation. The disinterested independence of police processes is central to the integrity of such processes. Both the fact and appearance of independence are central to the maintenance of public trust in policing. There are numerous situations where the private relationships and involvements of police officers can present an officer with a conflict of interest, undermine the impartiality of policing, and lead to a compromise in the administration of justice. ${ }^{124}$ In choosing to disclose information about a police case from a 'secure' database to a criminal who had an interest in the outcome of the police action, the police officer has breached the trust inherent in the office, this constituting misconduct in public office, against which the public has a right to be protected. It constitutes a breach of the public trust, because of the public interest in the nature of the information that was disclosed and its centrality to the effective functioning of the police force. The application of the misconduct in public office offence rather than of a lesser summary offence (for example, a prosecution under section 127A of the Police Regulation Act 1958 (Vic)) provides potential future offenders with an indication of the seriousness of the breach. ${ }^{125}$

The general principle that police officers should have the same freedom as ordinary citizens to engage in private pursuits and relationships, unhindered by regulation, is prima facie reasonable, on the basis that intrusion into anyone's private life should be minimal. However, this general position can reasonably be qualified in circumstances where a police officer may use his or her position to prey on the vulnerable. ${ }^{126}$ In relation to sexual misconduct or

\footnotetext{
${ }^{124}$ Davids, above $\mathrm{n} 3$.

${ }^{125}$ However, see D’Alo v Nolan [2006] VSC 362; DPP v Zierk (2008) 184 A Crim R 582; DPP $v$ Artz [2013] VCC 56 for examples of police misconduct involving the disclosure of confidential information which resulted in prosecutions under s 127A of the Police Regulation Act 1958 (Vic) rather than for the offence of misconduct in public office. The bases for DPP prosecutorial decisions such as these are not always clear. For example, the disclosure of information in DPP v Artz involved 'unauthorised disclosure to a journalist of information about an operation and impending raid directed at suspected terrorists' (Taft J at [1]). Although the disclosure did not produce serious consequences, it had the potential to do so, and the judge found that: 'the objective gravity of your offending does not allow for a monetary penalty' (at [32]); 'a sentence of imprisonment must be imposed, albeit wholly suspended' (at [34]); 'but for your plea of guilty ... most probably I would have imposed an actual term of imprisonment' (at [36]). The judge drew on comments from Nettle JA in DPP $v$ Marks [2005] VSCA 277, in order to emphasise the seriousness of the offence, and highlighted that the defendant had ' breached the trust reposed in [him] by Victoria Police' (DPP $\vee$ Artz at [34]). This would seem to present manifest circumstances for a charge of misconduct in public office, and the judge's references to Marks support this interpretation.

${ }^{126}$ See Davids, above n 3, 132.
} 
impropriety, police management can take any one or more of a number of disciplinary actions against officers. When an officer develops a close personal relationship with a person with whom he/she first came into contact during the course of police duties, allegations may be raised that the position of police officer was in fact used (abused) in order to facilitate and further such a relationship. This can amount to an abuse of trust - the trust both of the victim and the broader public. The matter of Quach illustrates a serious breach and confirms that liability for misconduct may occur in relation to matters arising when a public official is 'off duty'.

The case of Armstrong involved two key areas where the public trust was breached. First, when police officers abused their power and made false claims regarding the existence of search warrants, they knowingly breached multiple procedural safeguards developed to protect individual rights. Second, when police officers extorted money in exchange for a promise not to enforce the law, public trust and confidence in those officers was eroded and the flowon consequence for the organisation as a whole was a loss of trust. In an extreme form, this conduct can impact on the perceived legitimacy of policing. So, whilst the facts of this case supported separate charges against the police relating to possession of drugs and theft, there was also a need to charge them with an offence that captured the abuse of office and the breach of public trust inherent in behaviour that the court referred to as 'corrupt conduct'. The Court of Appeal expressly noted the need to deter police from extorting money or abusing power, recognising that in scenarios where police are dealing with criminals, the latter are unlikely to report corruption through fear that this will reveal their own involvement in offending.

In summary, the offence of misconduct in public office provides prosecuting authorities with an ability to charge a public official with an offence that reflects the fact that the circumstances of the offending amount to a non-trivial abuse of the public trust. The cases outlined above provide examples of the types of conduct and procedural breaches that courts in Australia, England and Hong Kong have found constituted misconduct in public office. The Australian jurisprudence exemplified in Quach seems to have more clearly articulated the key elements of the offence. Whilst Australia is yet to see the range of applications to public officials that has occurred in England, ${ }^{127}$ recent developments indicate that the offence may occur in numerous and varied employment scenarios, including privatised state services.

\footnotetext{
${ }^{127}$ For example, in England, a charge of misconduct in public office has recently been preferred against a retired Anglican bishop who allegedly sexually assaulted a number of boys between 1977 and 1992: 'Retired Bishop Peter Ball Faces Sex Offence Charges', BBC News England (online), 27 March $2014<$ http://www.bbc.com/news/uk-england-26771819>.
} 